IZA DP No. 5339

Private Wealth and Planned Early Retirement:

A Panel Data Analysis for the Netherlands, 1994-2009

Raun van Ooijen

Mauro Mastrogiacomo

Rob Euwals

November 2010 


\title{
Private Wealth and Planned Early Retirement: A Panel Data Analysis for the Netherlands, 1994-2009
}

\author{
Raun van Ooijen \\ De Nederlandsche Bank \\ Mauro Mastrogiacomo \\ CPB, VU University Amsterdam and Netspar \\ Rob Euwals \\ $C P B$ and IZA
}
Discussion Paper No. 5339
November 2010

IZA

P.O. Box 7240

53072 Bonn

Germany

Phone: +49-228-3894-0

Fax: +49-228-3894-180

E-mail: iza@iza.org

Any opinions expressed here are those of the author(s) and not those of IZA. Research published in this series may include views on policy, but the institute itself takes no institutional policy positions.

The Institute for the Study of Labor (IZA) in Bonn is a local and virtual international research center and a place of communication between science, politics and business. IZA is an independent nonprofit organization supported by Deutsche Post Foundation. The center is associated with the University of Bonn and offers a stimulating research environment through its international network, workshops and conferences, data service, project support, research visits and doctoral program. IZA engages in (i) original and internationally competitive research in all fields of labor economics, (ii) development of policy concepts, and (iii) dissemination of research results and concepts to the interested public.

IZA Discussion Papers often represent preliminary work and are circulated to encourage discussion. Citation of such a paper should account for its provisional character. A revised version may be available directly from the author. 
IZA Discussion Paper No. 5339

November 2010

\section{ABSTRACT}

\section{Private Wealth and Planned Early Retirement: A Panel Data Analysis for the Netherlands, 1994-2009*}

We study the causal relation between private wealth and retirement age. We propose two estimation strategies based on expected retirement age. The outcome variable is observed repeatedly over time. We correct first for the unobserved heterogeneity in the disutility of work by using panel data techniques. Next, we exploit information on expected wealth accumulation in order to identify the unexpected component in wealth accumulation. In line with the literature we find a small but significant effect of private wealth on planned early retirement.

JEL Classification: $\quad$ C23, J26

Keywords: early retirement, private wealth, subjective retirement expectations

Corresponding author:

Rob Euwals

CPB Netherlands Bureau of Economic Policy Analysis

P.O. Box 80510

2508 GM The Hague

The Netherlands

E-mail: r.w.euwals@cpb.nl

\footnotetext{
* The authors thank Casper van Ewijk, Hans Bloemen, Martin Browning, Marike Knoef, Hans van Kippersluis and participants of the ESPE 2010 in Essen, the EALE 2010 in London, the DIW 2010 in Berlin, and seminars at CPB and Netspar for useful comments. This research was conducted while the first author stayed at CPB. Views expressed in this paper are those of the authors and do not necessarily reflect official positions of De Nederlandsche Bank or CPB.
} 


\section{Introduction}

The average real level of financial wealth of Dutch Households has increased from $€ 28,000$ in 2000 to about $€ 48,000$ in $2007 .{ }^{1}$ Poterba (2000) shows a similar pattern for the United States between 1990 and 2000. Like most other countries Dutch citizens have witnessed a drop in the value of their wealth holdings due to the recession in years 2008 and 2009. The large increases and decreases in financial wealth holdings is of interest for current policy that aims to increase the labor force participation of elderly workers. Elderly workers may use the increased level of financial wealth to enjoy retirement earlier in life, while this desire may be opposed by an unexpected decrease in the level of financial wealth. It is therefore interesting to study the relation between private wealth and retirement plans.

The empirical evidence on the relationship between private wealth and retirement behavior is not particularly strong. Early contributions by Diamond and Hausman (1984) and Samwick (1998) investigate the effect of private wealth holdings in the United States in the 1970's and 1980's. Diamond and Hausman (1984) use data from the National Longitudinal Survey (NLS) of men who reach retirement between 1966 and 1976. They find that financial wealth has almost no effect on the timing of retirement. This is a somewhat surprising result. Differences in wealth holdings may be due to different saving decisions in the past. Individuals, who prefer to retire early, plan their saving behavior in order to be able to finance early retirement. This leads to an endogeneity problem when studying the causal effect of private wealth on retirement. The endogeneity should actually lead to an upward bias in the impact of private wealth on retirement. Likewise, Samwick (1998) finds a small positive but non significant effect of financial wealth on the probability of retirement, using data from the 1983 and 1986 Survey of Consumer Finances. For the Netherlands, Bloemen (2010), using data from the Socio-Economic panel for the years 1995 through 2002, finds a small and positive effect of financial wealth on the timing of retirement. ${ }^{2}$

The small wealth effect may be caused by other unobserved effects such as risk aversion. Those who are more concerned about a financially secure retirement will retire later and accumulate more wealth than those who are less concerned (Hurd 2009b). A standard approach in the literature to identify a causal wealth effect on the retirement age is to use unexpected changes in wealth which are unrelated to individual preferences, derived for instance from lotteries (Imbens, Rubin, and Sacerdote 2001), unexpected stock market appreciation or depreciation (Hurd 2009a) or received bequests (Holtz-Eakin, Joulfaian, and

\footnotetext{
${ }^{1}$ Households age 40 to 65 , source Dutch National Bank Household Survey (DHS).

${ }^{2}$ Using his results we have calculated that an increase in the level of wealth by an average yearly salary (about $€ 32,000$ ) leads to a decrease in the retirement age by six weeks. This implies an income effect of approximately 10 percent. This is computed relating the amount of weeks shift due to a one year salary exogenous shock, divided by 52 weeks.
} 
Rosen 1993). ${ }^{3}$ In our study, panel data will allow us to control for time-constant unobserved differences in preferences. We show new evidence on the effect of private wealth on retirement by using a panel dataset from the Netherlands from 1994 to 2009. We carry out two types of estimations that aim to isolate the causal effect of private wealth on retirement.

First, with repeated observations over time for the same individuals it is possible to control for unobserved, but time constant effects. Chan and Stevens (2004) use a similar strategy to study the effect of retirement incentives on retirement behavior. Since actual retirement (which generally means a permanent withdrawal from the labor market) will be observed only once, actual retirement behavior would be of little use in our analysis. We use a repeated question about the workers planned retirement age. As long as there are no unanticipated shocks, nor changes in financial literacy, the workers planned retirement age should stay constant over time. This is irrespective of the amount of wealth accumulation because of differences in preferences for early retirement.

The literature shows that the planned retirement age is a useful variable to study retirement behavior. Bernheim (1989) was the first to relate retirement expectations to realizations Disney and Tanner (2003) find that differences between the planned retirement age and the actual retirement age are related to health shocks and changes in marital status. A recent study by Benitez-Silva and Dwyer (2005) looks at the formation of retirement expectations more in depth. They provide evidence that individuals correctly anticipate most uncertain events when planning their retirement except for health related shocks.

One type of concern associated with panel data is that the unobserved effects might not be constant over time. Their might be other events, such as public discussions about future pension reforms, which are both associated with changes in wealth accumulation and the planned retirement age. The period of analysis is characterized by several pension debates which may affect individuals attitude towards the retirement age. Moreover, the individual disutility of work may increase over age because of physical constraints or health related problems. Such issues may alter the optimal consumption and employment path over the life cycle, affecting both wealth accumulation and retirement plans. We therefore show a second set of estimations. We isolate unexpected changes in wealth using data on self reported expectations about future wealth accumulation, rather than only relying on panel data techniques under the hypothesis of a constant disutility of work over time. Our

\footnotetext{
${ }^{3}$ Imbens, Rubin, and Sacerdote (2001) find that lottery winners spend about 11 percent of their prize on buying leisure. Holtz-Eakin, Joulfaian, and Rosen (1993) find that individuals who receive a large inheritance had a 18 percent greater chance to drop out of the labor force, though they might have anticipated bequest. Brown, Coile, and Weisbenner (2010) find that the causal impact of an unanticipated inheritance on the probability of retiring earlier is substantial. (Hurd 2009b) find no evidence that workers in households who had large stock market gains retired earlier than they had anticipated or that they revised their retirement expectations relative to workers in households that had no large gains.
} 
main result is that the effect of private wealth on the planned retirement age is statistically significant but small.

The paper is organized as follows. In Section 2 we briefly describe the evolution of the early retirement system in the Netherlands. In Section 3 we specify a simple theoretical model about the relationship between wealth and the planned retirement age and discuss how we use this model to estimate the wealth effect. In Section 4 we describe the data used in this analysis and show descriptive evidence of the relationship between the level of private wealth and the planned retirement age. In Section 5 we present the estimation results and section 6 concludes. In the Appendix we show the formal derivation discussed in Section 3 and discuss empirical findings on pension wealth.

\section{Dutch pension and early retirement system}

In the period of analysis there where several reforms of the early retirement system which significantly reduced the replacement rate for individuals who plan to retire early. We therefore first describe the evolution of the Dutch early retirement system during this period of time. ${ }^{4}$

The Dutch pension system is organized in a first and a second pillar. The first pillar is the public pension system. It provides a flat rate pension benefit, which is related to the net minimum wage. This is accessible at the statutory age of 65 . The second pillar consists of an occupational pension system, which covers most employees. Participation is mandatory for all employees when an employer offers a pension scheme. These pensions schemes are negotiated between unions and employers organizations at the sector or firm level. Because of this regulation, more than $80 \%$ of the Dutch workers are mandated to save in such a scheme (Bovenberg and Gradus 2008). Pension savings in the second pillar are facilitated by the government through a preferential tax treatment. There are large tax advantages on pensions savings due to the progressive tax system.

Since 2006, the Dutch early retirement system is integrated within the second pillar pension system. Before this date the early retirement system was separated. The early retirement scheme was introduced in the late 1970's and early 1980's to give elderly workers an incentive to retire before the age of 65 . Exact conditions varied by sector, but the early retirement scheme typically provided flat rate benefits that were equal to $80 \%$ of the last earned wage (Kapteyn and de Vos 1984). Furthermore, while in early retirement, the old age pension entitlement continued to grow even though the employee stopped working. The eligibility age of the early retirement schemes was typically 60 or 61 . Because of the

\footnotetext{
${ }^{4}$ In the Appendix we analyze the effect of the changes to pension wealth due to these policy shifts on planned retirement, which also appears to be modest.
} 
aging population and the low labor participation of the elderly, these pay-as- you-go early retirement schemes became an increasing burden for the working population and employers. From the late 1990's onwards the early retirement schemes were replaced by capital funded pre-pension schemes in which workers save for their own early retirement. In most sectors, it was decided to implement transitional arrangements in order to smooth the transition from the flat-rate early retirement schemes to the actuarially adjusted pre-pension schemes. The complete transition should be completed in 2022. The government still facilitated saving for early retirement in these pre-pension schemes by a special fiscal treatment as in the second pillar system.

As from January 1, 2006, the Dutch government installed a new law on early retirement. This law is called the Early Retirement and Life-Course Saving Arrangement Act (Wet VPL). The new law on early retirement abolished the special fiscal treatment for early retirement for individuals born after 1949. At the same time, the pre-pension schemes where transformed into actuarially fair schemes. This implied a substantial drop in pension benefits for people born after 1949 who planned to retire at the early entitlement age. For example, the replacement rate of public sector workers droped from 70 percent to 64 percent of average yearly earnings (de Grip, Lindeboom, and Montizaan 2009).

The life-course savings arrangement allows tax free saving up to 12 percent of annual earnings in a saving account that can be used to finance temporary leaves from work, such as sabbaticals, or early retirement. Individuals who where born in the years 1950 through 1954 are allowed to save more than 12 percent of their annual earning to supplement their early retirement savings. More than half of the individuals that participate in the lifecourse savings arrangement claim to do this for early retirement purposes. ${ }^{5}$ This makes early retirement by far the most important purpose to participate in the arrangement.

\section{$3 \quad$ Methodology}

\subsection{Theoretical Framework}

In this section we construct a simple theoretical framework to model the factors that affect the retirement age in order to introduce the estimation equation to assess the effect of private wealth on retirement. We consider a household $i$ who lives for a length of $T$ periods. For each period $t$ the household chooses how much to consume $c_{i t}$ and decides whether to work or retire. Our model is close to Bloom, Canning, Mansfield, and Moore (2007).

The function $\chi_{i t}$ indicates whether the household is working, $\chi_{i t}=1$ or retired, $\chi_{i t}=0$. We consider only full-time work or retirement and rule out gradual retirement since we are

\footnotetext{
${ }^{5}$ Source: Statistics Netherlands, Labor Force Survey.
} 
only interested in the participation decision. Workers earn the constant wage $w_{i}$ during working life which is added to wealth, while consumption $c_{i t}$ reduces wealth. The introduction of income uncertainty as in Hall (1978) leads to the accumulation of wealth as a buffer of precautionary saving. In our model we do not incorporate uncertainty. The unanticipated shocks to wealth are completely exogenous. We assume the wage to be constant over time to facilitate the optimization problem. A time varying wage would induce precautionary savings as an additional motive but would not alter our main conclusions. Households can borrow and lend as much as they desire at the interest rate $r$.

The household derives utility $U_{i}(\cdot)$ from consumption and disutility from working. ${ }^{6}$ The disutility of work $a_{i}$ differs between households and is constant over time. This implies that the total disutility of work increases when the household works longer because of additive preferences.

The household problem is to choose $c_{i t}$ and $\chi_{i t}$ to maximize the lifetime expected utility function.

$$
U_{i}=\int_{0}^{T_{i}} e^{-\delta t}\left[\left(u\left(c_{i t}\right)-\chi_{i t} a_{i}\right)\right] d t
$$

where future utility is discounted at the subjective rate of time preference $\delta$. The discount function is exponential which implies that delaying consumption reduces the value of consumption at a constant rate over time. Households maximize their lifetime expected utility subject to the budget constraint

$$
\frac{\partial A_{i t}}{\partial t}=\chi_{i t} w_{i}+r A_{i t}-c_{i t}
$$

where $A_{i t}$ represents the level of accumulated wealth in period $t$. We derive the following equations by taking the first-order conditions for a maximum in $c_{i t}$ and $\chi_{i t}$. Our derivation is similar to that of Bloom, Canning, Mansfield, and Moore (2007).

$$
\begin{gathered}
\frac{\partial c_{i t}}{\partial t}=(r-\delta) \frac{U_{i t}^{\prime}\left(c_{i t}\right)}{-U_{i t}^{\prime \prime}\left(c_{i t}\right)}, \\
\chi_{i t}=1 \Leftrightarrow U_{i t}^{\prime}\left(c_{i t}\right) w_{i} \geq a_{i} .
\end{gathered}
$$

\footnotetext{
${ }^{6}$ We ignore the consumption of leisure time. By including preferences for leisure-time in the life-cycle model, Heckman (1974) shows that individuals prefer to reduce hours of work gradually at later ages, labor supply choices at the intensive margin. We are only interested in the participation decision of elderly workers, the extensive margin. The exclusion of preferences for leisure simplifies our model without altering the main conclusions.
} 
The first equation implies that households prefer a rising level of consumption over the life-cycle if the interest rate is larger than the discount rate and the utility function is concave, i.e. $U_{i t}^{\prime \prime}\left(c_{i t}\right)<0$. This effect is small if the marginal utility of consumption falls quickly with the level of consumption. Which implies that households want to smooth consumption over their life-cycle, given their valuation of future consumption and the interest rate at which they are able to borrow and save. When the marginal utility of consumption in a particular period exceeds the marginal utility of consumption in other periods, households can increase utility by shifting resources from other periods to that particular period until the marginal utility is equalized across periods. Most empirical studies however find a discount rate that is larger than the interest rate implying that individuals are impatient and prefer current consumption over future consumption (Frederick, Loewenstein, and O'donoghue 2002).

The second equation implies that the household retires at time $t$ if the disutility of work exceeds the utility gain from more consumption by working longer (the marginal utility of consumption multiplied by the wage). Households with a higher disutility of work will retire earlier and have a lower level of consumption in each period (given the wage) relative to households who like working more. Which implies that they will hold more pre-retirement assets to finance the longer period of retirement without a sharp cutback in consumption.

The model states that households with a high disutility of work accumulate wealth for earlier retirement. However, when there are any remaining exogenous changes which affect the level of wealth upon retirement (given the wage) households should adjust their retirement plans and re-optimize their path of consumption. An unpredicted increase in wealth will lead to a higher level of accumulated assets. This will lead to a higher level of lifetime consumption. The higher level of consumption will induce a lower marginal utility of consumption. This increases the disutility of work and encourages earlier retirement.

To summarize, the relationship between wealth and planned retirement age (PRA) is endogenous. How much pre-retirement wealth (given the wage) a household accumulates depends on the planned retirement age which is determined by the disutility of labor. Furthermore, there is a causal impact of wealth (given the wage) on the planned retirement age, due to an unexpected (or in other words exogenous) increase in wealth. In a simple dynamic optimization framework, when the interest rate equals the rate of time preference, the basic relation can be written as $P R A_{i}=f\left(A_{i, t} / w_{i}, a_{i}\right)$ (see Appendix).

\subsection{Empirical model}

Theory suggests a (negative) relation between planned retirement age and wealth that we want to explore empirically. We focus on the relative level of wealth to (some measure of) permanent income, sometimes in the literature referred to as wealth rates. In the empirical 
analysis wealth will be divided by permanent income, also to account for distributional issues, as high-income households have larger wealth holdings. ${ }^{7}$

The regression equation of the planned retirement for household $i, P R A_{i}$ can be written as

$$
P R A_{i t}=\frac{A_{i t}}{w_{i}} \beta+X_{i t} \delta^{\prime}+a_{i}+\lambda_{t}+\pi_{c}+\epsilon_{i t},
$$

where $\frac{A_{i t}}{w_{i}}$ denotes the level of wealth relative to permanent income, $a_{i}$ is the disutility of labor, $X$ is a $1 \times K$ vector of socioeconomic variables. The time effects $\lambda_{t}$ control for unpredicted shocks during the period of analysis that affect the planned retirement age of all households in the same way. The cohort effect $\pi_{c}$ controls for differences in the planned retirement age between different year of birth cohorts. The cohort dependent pension reform described above being one of these. We construct a proxy for the level of permanent income following Kapteyn, Alessie, and Lusardi (2005). Socioeconomic attributes include characteristics that account for the planned retirement age, such as age, gender, marital status, number of children, education, health status, sector of employment (private or public), pension rights and other attributes that previous studies have found to be significant predictors of the retirement age.

The inclusion of cohort $\pi$, time $\lambda$ and age dummies in the model leads to an identification problem. This is because of the identity between the calendar year (time) and the year of birth (cohort) plus age. To solve the identification problem Deaton and Paxson (1994) transforms the time dummies to make them independent from the cohort and age dummies. The adjusted time dummies are based on two important assumptions. The time effects add up to zero and the coefficients are orthogonal to a linear trend. Due to this transformation, there are no real time effects. All transitory time effects are business cycle shocks instead of, for example, changes in preferences, and average out over time. ${ }^{8}$ In the regression analysis, we will use the transformed time dummies as in Deaton and Paxson (1994).

If we observed all relevant determinants of the planned retirement age, the least squares estimator of $\beta$ would be an unbiased estimator of the wealth effect. The standard problem of identifying $\beta$ is that we never observe all $X$ 's, and that wealth is likely to be correlated with the disutility of work that is unobservable.

\footnotetext{
${ }^{7}$ Previous studies have documented that the higher permanent income households have a higher level of financial wealth, see e.g. Diamond and Hausman (1984). Wealth rates are common controls in many microeconometric studies, see for instance Guiso, Jappelli, and Terlizzese (1992) and Carroll and Samwick (1998).

${ }^{8}$ Kapteyn, Alessie, and Lusardi (2005) propose to model cohort effects explicitly instead of using cohort dummies. They use cohort related variables like the level of GDP when the head of the household enters the labor market.
} 
Our empirical strategy to control for unobserved differences in the disutility of work $a_{i}$ between households, is to exploit variation in the level of wealth and the planned retirement age over time at the household level.

A prima facie option would be to estimate a fixed effect model. This would give the causal effect of wealth on the planned retirement age and it would remove any element that does not vary over time. The model does not allow us to estimate the effect of other variables of interest that are time invariant, like cohort related variables, education, permanent income and gender. Mundlak (1978) proposes to approximate the individual effect $\alpha_{i}$ by a linear function of the form $\alpha_{i}=\bar{x}_{i} \gamma+\omega_{i}$. The vector $\bar{x}_{i}$ includes all time averages of the explanatory variables. The coefficient $\gamma$ controls for possible correlation between the unobserved household-specific effect $\alpha_{i}$ and the regressors that are assumed to be uncorrelated to $\omega_{i}$. This boils down to estimating an extended version of the random effect model. It is further possible to identify the wealth effect using exogenous variation in wealth.

\section{Data and descriptive statistics}

\subsection{Data}

We use survey data from the Dutch Central Bank Household Survey (DHS) between 1994 and 2009 to estimate the effect of private wealth on the planned retirement age. The DHS is a longitudinal study that surveys Dutch households in order to study the the economic and psychological reasons behind saving behavior. The DHS interviews approximately 2000 households each year who participate in the CentER Internet panel. The DHS is sponsored by the Dutch Central Bank and is conducted by CentERdata, which is related to Tilburg University.

The DHS has a question about the planned retirement age and contains detailed information on various types of household assets and debts. We use this information to construct measures of household wealth. Net financial wealth includes money in checking and saving accounts, stocks, mutual funds, bonds, life insurance policies, annuity insurance policies, tax-favored saving schemes and other financial assets, net of financial debts such as private loans. Total wealth is the sum of net financial wealth (which we use as dependent variable in the models reported below) and non financial wealth, where the latter consists of durables goods, the perceived value of the house and other real estates net of mortgages. ${ }^{9}$

\footnotetext{
${ }^{9}$ If respondents do not know the amount of a certain component or refuse to answer the question, they are asked to select an interval within which their asset value lay, for instance "between $€ 1000$ and $€ 2000$ ". We use the middle value of the bracket as the value of the asset. These bracket questions reduce item non-response and result in more accurate measures of assets values. Missing values are imputed by Center Data. The assets are deflated to real 2009 euros.
} 
Pension wealth is another important component of household wealth. This is detained in compulsory saving accounts managed by pension funds and is not disposable. We therefore analyze this variable in a separate study.

After dropping observations due to some missing key information our sample consists of 23,877 observations and 7,762 different households. The descriptive analysis is based on this sample. The dependent variable in the analysis is the planned retirement age of the head of the household. This variable is based on the subjective question: "At what age do you expect to retire, or to make use of the early retirement arrangement". This question is asked in the first nine waves (until 2002) only to individuals above age 50. This reduces the sample to 7,232 observations and 2,255 households.

We work with a sub-sample of 3,881 observations and 1,290 households with non missing information on the planned retirement age, wealth and other independent variables in the empirical analysis. ${ }^{10}$ The rate of non response to the question concerning planned retirement age is lower than the non response rates of most other variables (see for instance the components of household wealth). The item non-response on retirement age might indicate that households are not able to report their planned retirement to poor financial literacy in the pension domain. However the lower non response on retirement plans, compared to other questions in the wealth questionnaire, suggests the opposite. The many missing items in planned retirement age are due to the survey design, as explained above.

Table 1 reports the means and standard deviations of the main variables in our analysis. We report these statistics for the full sample and the sub-sample with non missing information. The table shows that both samples are quite similar when it comes to the planned retirement age, which suggests that selection for this variable might not be an issue. The planned retirement age of households in the sub-sample is on average 62.9 years. Households in the sub-sample are on average 4.3 years older. The survey design is responsible for this. In some years only 50 plus respondents are asked about their planned retirement. These individuals are consequently somewhat wealthier: the level of net financial wealth is 0.38 permanent income higher (about $€ 10.300$ ), the level of net housing wealth is 0.89 permanent income higher (about $€ 24,100$ ), and they have on average six additional years of contribution to the pension fund. Households in the sub-sample have a higher level of education and a higher perceived health status. Other characteristics, like the sector of employment, family size and gender are similar.

\footnotetext{
${ }^{10}$ We loose observations because of missing information about asset ownership (about 2180), non response on the question about the planned retirement age (about 1220), missing information about permanent income (about 1590), missing school classification (about 50), missing self reported health status (about 910) and missing information about the sector of employment (about 550).
} 
Table 1: Summary Statistics ${ }^{a}$

\begin{tabular}{|c|c|c|c|c|}
\hline & \multicolumn{2}{|c|}{ Full Sample } & \multicolumn{2}{|c|}{ Sub-sample } \\
\hline & Mean & Std. & Mean & Std. \\
\hline Planned retirement age & 62.9 & 3.08 & 62.9 & 2.96 \\
\hline Total wealth ${ }^{b}$ & 5.39 & 11.3 & 6.68 & 11.1 \\
\hline Net financial wealth ${ }^{b}$ & 2.29 & 2.99 & 2.67 & 3.03 \\
\hline Net housing wealth ${ }^{b}$ & 3.47 & 7.57 & 4.36 & 7.60 \\
\hline Savings ${ }^{b}$ & 0.11 & 1.63 & 0.11 & 1.70 \\
\hline Years of contribution to the pension fund & 17.5 & 12.0 & 23.5 & 11.3 \\
\hline Net income $(€ 1,000)$ & 29.3 & 19.2 & 32.4 & 18.3 \\
\hline Permanent income $^{c}(€ 1,000)$ & 26.0 & 16.2 & 27.1 & 13.1 \\
\hline Age & 44.3 & 10.4 & 48.5 & 9.59 \\
\hline Gender (male) & 0.78 & 0.38 & 0.83 & 0.37 \\
\hline Education (high) & 0.39 & 0.49 & 0.47 & 0.50 \\
\hline Education (intermediate) & 0.34 & 0.47 & 0.30 & 0.46 \\
\hline Education (low) & 0.27 & 0.44 & 0.24 & 0.42 \\
\hline Health (good) & 0.80 & 0.38 & 0.85 & 0.35 \\
\hline Health (poor) & 0.20 & 0.38 & 0.15 & 0.35 \\
\hline Family size & 2.54 & 1.39 & 2.46 & 1.32 \\
\hline Partner (yes) & 0.67 & 0.44 & 0.69 & 0.45 \\
\hline Civil Servant & 0.20 & 0.40 & 0.22 & 0.42 \\
\hline Number of observations & 23,877 & & 3,881 & \\
\hline
\end{tabular}

\footnotetext{
${ }^{a}$ Source: authors tabulations of 1994 to 2009 DNB Household Survey. Sample consists of all

households with head of the household aged 25-65. All euro amounts are in 2009 euros. The statistics use sample weights.

${ }^{b}$ Divided by permanent income.

${ }^{c}$ Our proxy of permanent income replicates that in Kapteyn, Alessie, and Lusardi (2005), and is therefore based on estimating income equations to predict future non capital income.
}

\subsection{Descriptive analysis}

Figure 1 plots the planned retirement age according to age for different year of birth cohorts. The vertical distance among the segments indicates that younger cohorts have a higher planned retirement age at most ages. In particular, the cohorts born after 1949 plan to retire at an older age. This may clearly be related to the reforms of the early retirement schemes. An important reform took place on January 1, 2006 which abolishes the fiscal facilitation of pre- pension rights of individuals born after 1949. The planned retirement age is postponed by about 1.5 years for the younger cohorts, born after 1949 .

Table 2 shows descriptive data on components and distribution of household wealth for households with the head of the household aged 40 to 60 . There are many households who have little private wealth holdings. A quarter of the households have less than $€ 11,000$ in total wealth and less than $€ 900$ in financial wealth. Half of the households have less than 
Figure 1: Planned retirement by age and cohort $^{a}$

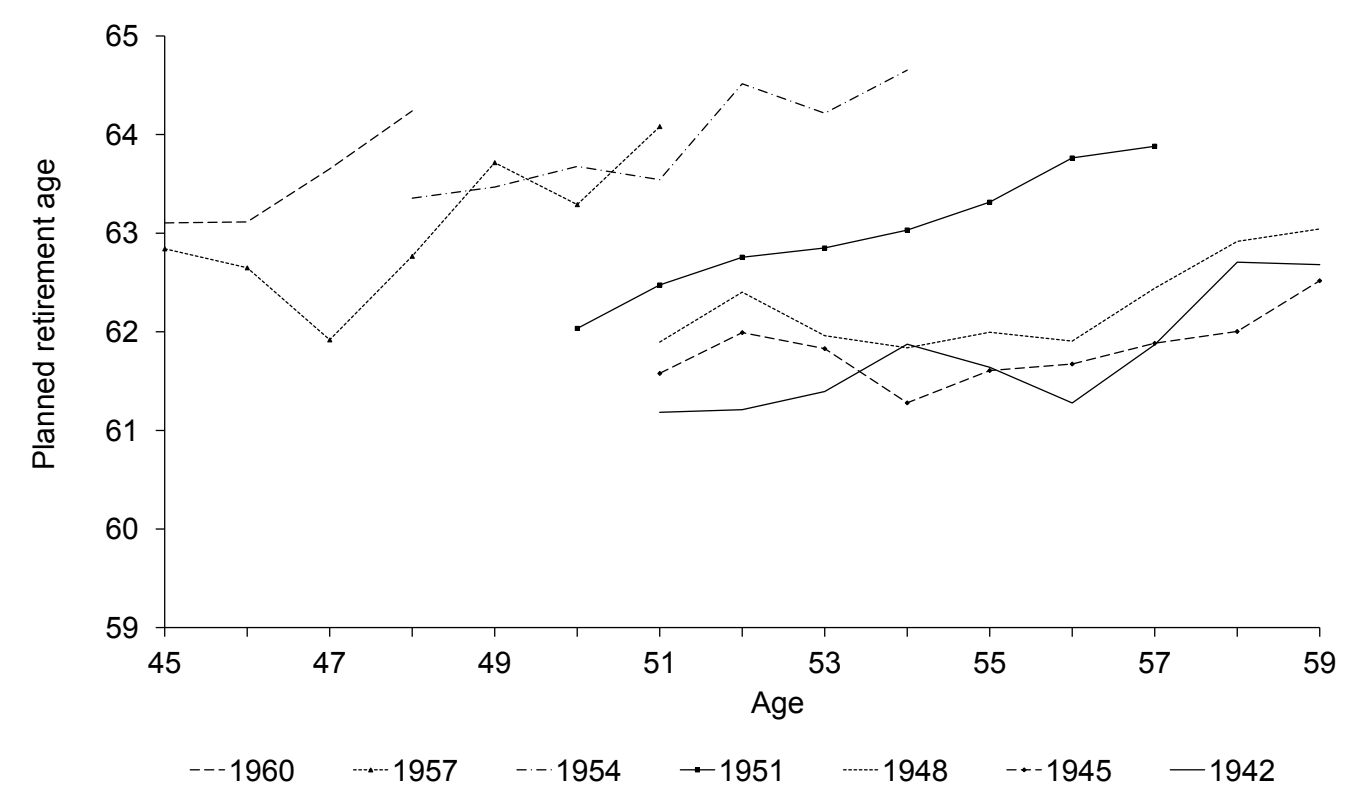

\footnotetext{
${ }^{a}$ Source: 1994 to 2009 DNB Household Survey. Sample consists of all households with head of the household aged 45-60. The statistics use sample weights.

We use 3-year intervals to define year of birth cohorts, with birth year 1959-1961 (1960) for the youngest cohort up to 1941-1943 (1942). Each point on the cohort- curve represents the average age of the cohort at the time of the survey.
}

$€ 82,200$ in total wealth and less than $€ 9,100$ in financial wealth. This level of savings is evidently not enough to purchase an annuity that would substantially increase retirement income. To illustrate, a 65 year old men purchasing a $€ 9,100$ single premium annuity at age 65 would receive a monthly payment of $€ 72$ or $€ 867$ per year for life, see Mitchell, Poterba, and Warshawsky (1999). While a large fraction of the households has little financial assets, a relatively small group has substantial wealth holdings. A quarter of the households have more than $€ 191,300$ in total wealth and $€ 32,400$ in financial wealth. Net housing wealth is an important asset and perhaps one of the main vehicles to accumulate wealth, 59 percent of the households has housing equity and half of the homeowners have more than $€ 123,500$ in housing equity. ${ }^{11}$ Households keep most of their financial wealth in safe financial assets, as checking or saving accounts and invest relatively small amounts in risky assets or in fairly

\footnotetext{
${ }^{11}$ Beside this amount could even be underestimated as the period under review is characterized by a rapid increase in wealth. The booming of the housing market might have left some individuals not aware of their passive gains on housing wealth. House prices decreased moderately in the Netherlands as a result of the 2008-2009 recession.
} 
safe assets like annuities. Only a few households invest substantial amounts in these assets.

Table 2: Components and Distribution of Household Wealth with head aged 40-60

\begin{tabular}{|c|c|c|c|c|c|c|c|}
\hline & \multirow[b]{2}{*}{ Mean } & \multirow[b]{2}{*}{ Own } & \multicolumn{5}{|c|}{ Households with nonzero amounts } \\
\hline & & & $\begin{array}{l}25 \\
\text { Pctile }\end{array}$ & Median & $\begin{array}{l}75 \\
\text { Pctile }\end{array}$ & Mean & $\mathrm{Sd}$ \\
\hline Total Wealth & 134,200 & 98.2 & 11,000 & 82,200 & 191,300 & 136,700 & 212,500 \\
\hline Net Financial Wealth & 28,400 & 96.1 & 900 & 9,100 & 32,400 & 29,600 & 74,900 \\
\hline Net Housing Wealth & 87,600 & 59.0 & 70,000 & 123,500 & 191,800 & 148,500 & 143,000 \\
\hline Safe assets ${ }^{b}$ & 14,500 & 91.4 & 2,200 & 6,700 & 17,200 & 15,800 & 30,600 \\
\hline Fairly Safe assets ${ }^{c}$ & 9,000 & 38.3 & 2,100 & 8,400 & 24,700 & 23,400 & 44,700 \\
\hline Risky assets $^{d}$ & 8,500 & 23.5 & 3,100 & 11,200 & 30,600 & 36,100 & 89,600 \\
\hline
\end{tabular}

${ }^{a}$ Source: authors tabulations of 1994 to 2009 DNB Household Survey. Sample consists of all

households with head of the household aged 40 to 60. All euro amounts are in 2009 euros. The

statistics use sample weights.

${ }^{b}$ Safe financial assets include checking and saving accounts, certificates of deposit and

employer-sponsored savings plans.

${ }^{c}$ Fairly safe financial assets include defined contribution plans, the cash value of life insurances and other financial assets.

${ }^{d}$ Risky financial assets include stocks, bonds, mutual funds and/or mutual fund accounts.

Figure 2 plots the level of net financial wealth according to age for different year of birth cohorts. There are two patterns which emerges from this figure. First, not surprisingly, the level of financial wealth increases with age, which is central to the life cycle model. Second, there is a sharp increase in the level of financial wealth over subsequent generations. The level of financial wealth for households aged 50 and born in 1949 is about $€ 20,600$, while for households born in 1955 the level of financial wealth is about $€ 31,700$. The younger generations may use this increased level of financial wealth to finance early retirement.

Table 3 explores the relationship between the level of accumulated wealth and early retirement. As early retirement has become more expensive after the reforms of the early retirement system, the difference in the planned retirement age between households with different levels of financial wealth should be particularly apparent in more recent years. It is also interesting to look at the relation between planned retirement age and wealth over different periods as the sharp increases in wealth characterized the years between 1998 and 2004 more than the periods before or after. The table shows the ownership and average amounts of different components of household wealth for those who plan to retire early (before age 63) and for those who do not plan to retire early (at age 63 or later). Workers who plan to retire early in the years 2005 to 2009 (and in 1998 to 2004) own significantly more financial wealth than similar workers in the year 1994 to 1997. The average amount of net financial wealth more than doubled (€ 29,400 in 1997 and $€ 76,900$ in 2009). The 
Figure 2: Net financial wealth by cohort and age 25 to $65^{a}$

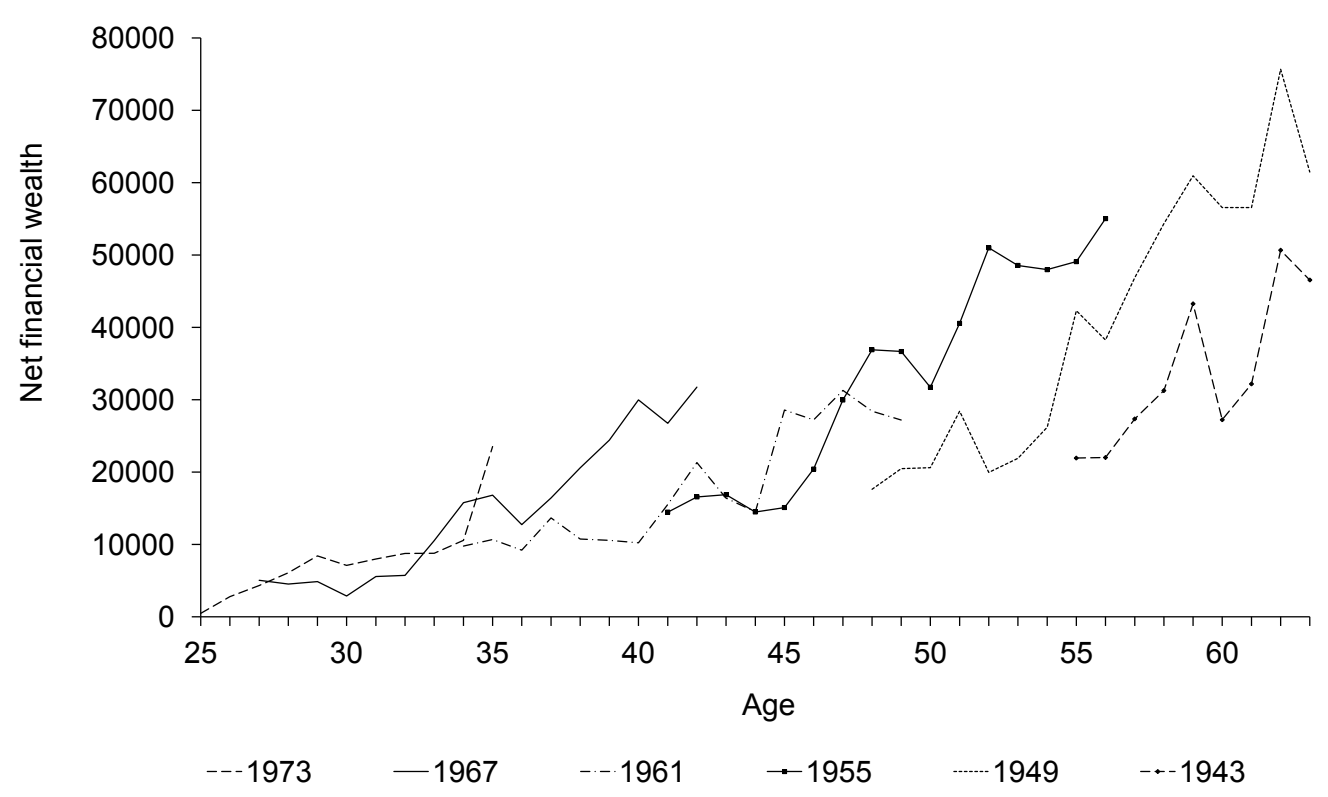

\footnotetext{
${ }^{a}$ Source: 1994 to 2009 DNB Household Survey. Sample consists of all households with head of the household aged 25 to 65 . All euro amounts are in 2009 euros. The statistics use sample weights. We use 7-year intervals to define year of birth cohorts, with birth year 1970-1976 (1973) for the youngest cohort up to 1940-1946 (1943). Each point on the cohort-curve represents the average age of the cohort at the time of the survey.
}

difference in the level of net financial wealth between both groups is statistically significant in the years 2005 to 2009. The difference in savings behavior between individuals who plan to retire early and individuals who plan to retire late may also be reflected by the ownership of different assets. The table shows that workers who plan to retire early more often invest in risky assets and housing equity in the years 2005 to 2009 .

These differences in wealth holdings between both groups, which are statistically significant for most components of wealth, give the impression that wealthier individuals plan to retire earlier, especially in more recent years. They are not conclusive since they fail to control for other factors, like permanent income, education and health, that are related to both wealth and the planned retirement age. Moreover, the descriptive evidence gives no information about the direction of causality between wealth and the planned retirement age. 
Table 3: Wealth and asset allocation by planned retirement age (PRA) ${ }^{a}$

\begin{tabular}{lllllll}
\hline & \multicolumn{2}{c}{ PRA $1994-1997$} & \multicolumn{2}{c}{ PRA $1998-2004$} & \multicolumn{2}{c}{ PRA 2005-2009 } \\
& $<63$ & $\geq 63$ & $<63$ & $\geq 63$ & $<63$ & $\geq 63$ \\
\hline & \multicolumn{7}{c}{ a. Mean value $€ 1000$} \\
Total Wealth & 133.7 & 147.4 & $226.8^{*}$ & $160.5^{*}$ & $288.0^{*}$ & $200.6^{*}$ \\
Net Financial Wealth & 29.4 & 38.4 & 51.5 & 35.6 & $76.9^{*}$ & $42.7^{*}$ \\
Net Housing Wealth & 128.1 & 133.6 & $226.2^{*}$ & $173.2^{*}$ & $236.0^{*}$ & $214.9^{*}$ \\
Safe assets & 12.3 & 12.5 & $25.8^{*}$ & $19.6^{*}$ & $38.8^{*}$ & $24.2^{*}$ \\
Fairly Safe assets & $33.5^{*}$ & $43.1^{*}$ & 27.5 & 25.7 & $41.0^{*}$ & $28.7^{*}$ \\
Risky assets & 32.9 & 43.2 & $51.9^{*}$ & $27.0^{*}$ & $51.2^{*}$ & $28.6^{*}$ \\
& \multicolumn{7}{c}{ b. Asset Ownership } & & & \\
Total Wealth & 98.3 & 98.5 & 99.4 & 99.6 & 99.4 & 99.8 \\
Net Financial Wealth & 96.1 & 95.0 & 99.2 & 98.3 & 99.5 & 99.8 \\
Net Housing Wealth & 67.9 & 66.6 & $67.3^{*}$ & $55.0^{*}$ & $79.1^{*}$ & $62.4^{*}$ \\
Safe assets & 92.7 & 89.3 & $98.7^{*}$ & $94.0^{*}$ & $95.7^{*}$ & $98.7^{*}$ \\
Fairly Safe assets & 39.6 & 40.2 & 45.1 & 48.4 & 57.3 & 49.0 \\
Risky assets & 22.0 & 27.1 & 32.6 & 28.6 & $37.8^{*}$ & $27.1^{*}$ \\
Observations & 757 & 428 & 612 & 313 & 445 & 624 \\
& & & & & \\
\hline
\end{tabular}

\footnotetext{
${ }^{a}$ Source: 1994 to 2009 DNB Household Survey. Sample consists of all households with head of the household aged 50-60. All euro amounts are in 2009 euros. The statistics use sample weights.

The sample is split up in two groups for those who which to retire early (before age 63) and one for those who do not which to retire early (at age 63 or later). The table shows the percentages of individuals who own a certain type of asset and the amount of wealth for those who do own a particular asset.

T- test: * Both groups significantly differ at the $1 \%$ confidence level.
}

\section{$5 \quad$ Results}

\subsection{Effect of private wealth on the planned retirement age}

Table 4 shows the regression results. The first column contains the regression estimates of the planned retirement age without controlling for possible unobserved heterogeneity. The second column includes time averages of the endogenous variables to account for unobserved heterogeneity that is possibly correlated with the regressors.

We first discuss the results for column 1 . The level of financial wealth relative to permanent income has a small negative coefficient of -0.073 and is significant at the $1 \%$ level. The coefficient indicates that households that have one additional unit of permanent income in financial wealth (about $€ 27,100)$ plan to retire 0.073 years earlier (about 4 weeks). The average level of permanent income is somewhat lower compared to the average net income in the sample. We have calculated that an additional average year salary (about $€ 32,400$ ) implies 4.5 weeks earlier retirement. That is an income effect of -8.7 percent. This is com- 
Table 4: Regression results on the planned retirement age (in years) ${ }^{a}$

\begin{tabular}{|c|c|c|}
\hline & Random effect & Mundlak specification \\
\hline \multicolumn{3}{|l|}{ Wealth Measures } \\
\hline Net financial wealth ${ }^{b}$ & $-0.073^{* * *}$ & $-0.063^{* * *}$ \\
\hline Net housing wealth ${ }^{b}$ & $-0.015^{*}$ & -0.007 \\
\hline Contributing years to the pension fund & $-0.021^{* * *}$ & 0.001 \\
\hline \multicolumn{3}{|l|}{ Socio economic variables } \\
\hline Higher education & $0.815^{* * *}$ & $0.619^{* * *}$ \\
\hline Intermediate education & 0.174 & 0.087 \\
\hline Poor health status & -0.122 & 0.001 \\
\hline Male & 0.211 & $0.628^{* * *}$ \\
\hline Partner & 0.030 & $0.882^{* * *}$ \\
\hline Family size & -0.018 & -0.064 \\
\hline Civil servant & $-0.258^{*}$ & -0.206 \\
\hline Permanent income $(€ 1,000)$ & $-0.017^{* *}$ & $-0.012^{*}$ \\
\hline Constant & $54.354^{* * *}$ & $55.506^{* * *}$ \\
\hline \multicolumn{3}{|l|}{ Age, time and cohort effects ${ }^{c}$} \\
\hline Year dummies & $\chi_{14}^{2}=37.4^{* * *}$ & $\chi_{14}^{2}=37.2^{* * *}$ \\
\hline Cohort dummies & $\chi_{9}^{2}=84.0^{* * *}$ & $\chi_{9}^{2}=71.9^{* * *}$ \\
\hline Age spline & $\chi_{8}^{2}=38.0^{* * *}$ & $\chi_{8}^{2}=35.6^{* * *}$ \\
\hline Time averages $^{d}$ & & $\chi_{7}^{2}=64.5^{* * *}$ \\
\hline Marginal effect ${ }^{e}$ (weeks) & -4.5 & -3.9 \\
\hline Income effect ${ }^{e}(\%)$ & -8.7 & -7.5 \\
\hline Observations & 3881 & 3881 \\
\hline
\end{tabular}

${ }^{a}$ Source: 1994 to 2009 DNB Household Survey. Sample consists of all households with head of the household aged 25 to 65 . All euro amounts are in 2009 euros.

* is significant at $10 \%$ level; $* *$ is significant at $5 \%$ level; $* * *$ is significant at $1 \%$ level.

${ }^{b}$ Divided by permanent income.

${ }^{c}$ Age, year and cohort effects are not reported.

${ }^{d}$ The time averages include the following variables: Net financial wealth, Net housing wealth,

Contributing years to the pension fund, Poor health status, Partner, Family size and Civil Servant.

${ }^{e}$ Relative to 52 weeks for 1 year. 
puted relating the amount of weeks shift due to a one year salary exogenous shock, divided by 52 weeks. The small magnitude of the coefficient is in line with the literature quoted above, which suggests that the correlation between wealth and the timing of retirement is small.

The estimated coefficient of net housing wealth (-0.015) is much smaller compared to the coefficient of financial wealth but statistically significant. The small coefficient is remarkable given the large increase in housing prices in the observed period. The strong increase in housing wealth could have resulted in a higher take-up of the surplus value on the house (van der Schors, Alessie, and Mastrogiacomo 2007). This suggests that housing wealth is of minor importance in the retirement decision, which confirms previous empirical findings. An explanation offered by Skinner (1996) is that individuals use housing wealth as a precautionary buffer against a decline in health or widowhood and therefore do not use housing wealth to finance early retirement.

The variable that measures the number of contributing years to the pension fund has a negative coefficient of -0.021 and is significant at the $1 \%$ level. This indicates that households who have contributed one additional year to the pension fund expect to retire about one week earlier. Even though we do not know the exact level of accumulated pension wealth, this suggests that the level of pension wealth has a negative and significant effect on the planned retirement age. Chan and Stevens (2004) report a negative and significant effect of pension wealth on retirement plans as well.

We have also added other usual controls to these specifications (e.g. health status, education, gender, marital status). As to the usual controls, the coefficient for bad health is negative but not significant. This result is not in line with other studies. For example, Dwyer and Mitchell (1999) show that bad health is an important determinant for the timing of retirement. Using data from the HRS they find that men in poor health expect to retire one to two years earlier. A possible explanation for the non significant effect of health on the planned retirement age is that workers who are in poor health and therefore expect to retire early through disability insurance do not answer the question about the planned retirement age in the DHS. Early retirement schemes of workers in the public sector are known to be more generous than for workers in the private sector (see Euwals, van Vuuren, and Wolthoff (2010) for a detailed description of the early retirement schemes of civil servants). Public sector workers expect to retire about three months earlier compared to workers in the private sector. Workers with a low level of education plan to retire about 10 months earlier compared to people with a high level of education. The family size, marital status and gender do not have a generally significant effect on the planned retirement age.

In order to address the possibility of unobserved heterogeneity that is correlated with the regressors, the second column in Table 4 repeats the analysis using the extended spec- 
ification. If there are important unobserved variables such as the disutility of work that are positively correlated with the planned retirement age and with the wealth variables, we would expect to find a smaller coefficient for the measures of wealth. There is a small reduction in the coefficient of financial wealth $(-0.063)$. This suggests that financial wealth has a causal impact on early retirement and that individuals do not explicitly save to finance early retirement. If individuals end up with a larger amount of financial wealth than expected, than they use this increased wealth to finance earlier retirement. The coefficient for housing wealth is statistically not significant.

The coefficient for the number of contributing years to the pension fund becomes statistically insignificant. This suggests that having a break in pension contributions does not affect retirement plans and that there are omitted variables that are correlated with the number of contributing years. Chan and Stevens (2004) show that workers with a high disutility of work are more likely to join early retirement schemes that have generous conditions. When individuals, who have not saved sufficient using their occupational pensions, self-select themselves into generous early retirement plans this will bias the results.

Finally the significance of the time averages in the second column $\left(\chi_{7}^{2}=64.5\right)$ suggests that there are unobserved effects that affects the planned retirement age and the observed time varying characteristics.

\subsection{Results using unexpected changes in wealth}

Our results indicate that when a household experiences a wealth shock, the head of the household expects to retire earlier. There is, however, one limitation to this result. The key to the Mundlak estimation is that the unobserved heterogeneity is constant over time and correlated with independent variables. However that unobserved heterogeneity is constant after a wealth shock could be too restrictive here.

To address this concern, we make use of a question about expected wealth accumulation in the data: "Are you planning to put money aside in the next 12 months?" Answers to this question are grouped in 4 categories: 1) yes, certainly, 2) yes, perhaps, 3) probably not, 4) certainly not. We select all those who answer "yes, certainly" but manage to save zero or a negative amount a year later, and those who answer "certainly not" but are observed one year later having accumulated some wealth. Notice that we have no information on the amount of savings targeted in one's expectations. We estimate separate coefficients of the change in wealth rates on the planned retirement age for those with expected and unexpected wealth changes between two adjacent time periods. The change in wealth includes both active savings and passive savings as capital gains and net transfers into the household (e.g. inheritances). The results of this analysis are shown in Table 5.

In column 1 we consider the whole sample. This is a smaller sample relative to the 
previous estimation. This is due to missing values for savings and expected wealth accumulation. The effect of a wealth change (saving relative to the level of permanent income) on the planned retirement age is -0.040 and is significant at the $10 \%$ level. This implies that raising the level of savings with $€ 32.400$ (average net income) increases the planned retirement age with 2.5 weeks. Which implies an income effect of -4.8 percent. The income effect is smaller than the previous estimations, but again in line with results from other studies on the effect of pension wealth on retirement, see e.g. (Euwals, van Vuuren, and Wolthoff 2010). Column 2 isolates those who experienced an unexpected change in wealth. It shows that an increase in savings with $€ 32.400$ leads to a reduction of the planned retirement age of 9 weeks. This indicates that wealth changes that are unexpected have much larger effects on the planned retirement age than changes that might be expected.

Notice that a direct comparison with the effect of total wealth is not possible, as the effect of the unexpected wealth change is hidden within the rest of the endogenous components that we already discussed. This line of thinking is used also in Brown, Coile, and Weisbenner (2010) who isolate the group of unexpected inheritance receivers. In their study the effect of a dollar of inheritance on the probability of retiring early is more than twice as large if the inheritance is unexpected.

Preferences for early retirement can also vary over time. For example individuals who experience a shock in health status, may suddenly develop a stronger taste for early retirement and wealth may drop at the same time. This does not undermine our results, but poses a problem if such shift occurs between $t-1$ and $t$, that is to say between the moment when expectations are registered $(t-1)$ and realizations are observed $(t)$. If this shift in preference takes place at that time, then it is unclear whether the effect we find is due to an exogenous change in wealth or to a shift in preferences. We address the issue of endogenous preferences by instrumenting wealth. In this approach the main problem is choosing an instrument. The literature on dynamic panel data models like the one of Arellano and Bond (1991) propose to use lags of the explanatory variable. Due to the short panel (households are on average observed for three time periods), this strategy was unsuccessful. The drop in observations was large and made the estimates unreliable. It is important to take this issue into consideration when interpreting the results in Column 3 of Table 5, where most of the interesting coefficients loose statistical significance. Due to data limitations no other strong instruments are available. Weaker instruments, such as the occurrence of divorce delivered unreliable results that are not worth reporting.

We take the results of the unexpected wealth change in Column 2 of Table 5 as our preferred results. We corrected for individual fixed effects, including time- constant preferences for early retirement, and we corrected for changes in behavior that may have occured before time t- 1 by using unexpected changes in wealth. We assume that the largest part of the 
shocks in wealth and savings occurs because of unexpected events unrelated to preferences for early retirement, like unexpected drops in wealth holdings and unexpected increases in costs of living.

Table 5: Random effect results for the planned retirement age depending on expectations of wealth changes one period in the past (Mundlak specification) ${ }^{a}$

\begin{tabular}{|c|c|c|c|}
\hline & Whole sample & $\begin{array}{l}\text { Unexpected } \\
\text { wealth change }\end{array}$ & $\begin{array}{l}\text { IV for unexpected } \\
\text { changes }^{e}\end{array}$ \\
\hline Saving $^{b}$ & $-0.040^{*}$ & $-0.154^{* *}$ & -0.043 \\
\hline Net housing wealth ${ }^{b}$ & -0.014 & $-0.071^{* *}$ & -0.06 \\
\hline Contributing years to the pension fund & 0.005 & 0.03 & 0.029 \\
\hline \multicolumn{4}{|l|}{ Socio economic variables } \\
\hline Higher education & $0.576^{* * *}$ & $0.855^{* *}$ & 0.771 \\
\hline Intermediate education & 0.068 & 0.290 & 0.554 \\
\hline Poor health status & 0.003 & 0.003 & -0.193 \\
\hline Male & $0.533^{*}$ & 0.812 & 0.655 \\
\hline Partner & $1.050^{* * *}$ & 0.839 & 0.231 \\
\hline Family size & -0.113 & -0.076 & -0.198 \\
\hline Civil servant & -0.122 & $-1.656^{*}$ & -0.942 \\
\hline Permanent income $(€ 1,000)$ & $-0.022^{* *}$ & $-0.038^{* *}$ & -0.014 \\
\hline Constant & $58.392^{* * *}$ & $85.407^{* * *}$ & $101.881^{* * *}$ \\
\hline \multicolumn{4}{|l|}{ Age, time and cohort effects ${ }^{c}$} \\
\hline Year dummies & $\chi_{13}^{2}=34.5^{* * *}$ & $\chi_{13}^{2}=9.8$ & $\chi_{12}^{2}=8.8$ \\
\hline Cohort dummies & $\chi_{9}^{2}=22.5^{* * *}$ & $\chi_{9}^{2}=5.2$ & $\chi_{8}^{2}=6.6$ \\
\hline Age spline & $\chi_{8}^{2}=23.3^{* * *}$ & $\chi_{8}^{2}=18.0^{* *}$ & $\chi_{8}^{2}=5.1$ \\
\hline Time averages $^{d}$ & $\chi_{7}^{2}=57.5^{* * *}$ & $\chi_{7}^{2}=18.3 * *$ & $\chi_{7}^{2}=13.5^{*}$ \\
\hline Marginal effect (weeks) & -2.5 & -9.4 & -2.7 \\
\hline Income effect $(\%)$ & -4.8 & -18.1 & -5.1 \\
\hline Observations & 2730 & 502 & 309 \\
\hline
\end{tabular}

${ }^{a}$ Source: 1994 to 2009 DNB Household Survey. Sample consists of all households with head of the household aged 25-65. All euro amounts are in 2009 euros.

* is significant at $10 \%$ level; $* *$ is significant at $5 \%$ level; *** is significant at $1 \%$ level.

${ }^{b}$ Divided by permanent income.

${ }^{c}$ Age, year and cohort effects are not reported.

${ }^{d}$ The time averages include the following variables: Net financial wealth, Net housing wealth, Contributing years to the pension fund, Poor health status, Partner, Family size and Civil Servant.

${ }^{e}$ Instrument is saving divided by permanent income in $t-1$ and $t-2$. 


\section{Conclusion}

We investigate the effect of wealth accumulation on the planned retirement age. Recent policy measures aiming to increase the labor participation of elderly workers gives individuals more flexibility in determining the retirement age. Private wealth holdings therefore become more important for the timing of retirement. In addition, the level of private wealth holdings of households has increased considerably over the last decade. Elderly workers may use the increased level of private wealth to finance longer periods of retirement. This may lead to a downward trend towards earlier retirement.

We find that high wealth individuals plan to retire earlier compared to low wealth individuals. The magnitude of the association between financial wealth (relative to permanent income) and the planned retirement age is small, implying that the level of financial wealth is of minor importance for the retirement decision. When we establish a causal relation of financial wealth on the planned retirement age, we find a larger effect of increased wealth in financing earlier retirement (an income effect of 18 percent). We have obtained this result first assuming a constant disutility of work and estimating an extended specification of the random effects model, and then isolating the exogenous changes in wealth due to an unexpected wealth outcome. Housing wealth is an important component of private wealth, but individuals do not seem to be using housing wealth to finance earlier retirement.

The question about subjective retirement expectations thus seems a useful variable to study retirement behavior to control for unobserved heterogeneity in the disutility of labor. The causal effect of wealth on the planned retirement age is not particularly large and corresponds with earlier findings of wealth on actual retirement behavior. In future research, it is relevant to analyze if individuals actually retire on the planned retirement age.

\section{References}

Arellano, M., and S. Bond (1991): "Some Tests of Specification for Panel Data: Monte Carlo Evidence and an Application to Employment Equations," The Review of Economic Studies, 58, 277-297.

Benitez-Silva, H., and D. S. Dwyer (2005): "The Rationality of Retirement Expectations and the Role of New Information," Review of Economics and Statistics, 87, 587-592.

Bernheim, D. (1989): The Economics of Agingchap. The Timing of Retirement: A Comparison of Expectations and Realizations, pp. 335-358. University of Chigago Press.

Bertrand, M., E. Duflo, and S. Mullainathan (2004): "How Much Should We Trust Differences-in-Differences Estimates?," Quarterly Journal of Economics, 119, 249-275. 
Bloemen, H. (2010): "The Effect of Private Wealth on the Retirement Rate: An Empirical Analysis," Economica, Forthcoming.

Bloom, D. E., D. Canning, R. K. Mansfield, and M. Moore (2007): "Demographic change, social security systems, and savings," Journal of Monetary Economics, 54, 92114 .

Bovenberg, L., and R. Gradus (2008): "Dutch Policies Towards Ageing," European View, 23, 265-275.

Brown, J., C. Coile, and S. Weisbenner (2010): "The effect of Inheritance Reciept on Retirement," Review of Economics and Statistics, 92, 425-434.

Carroll, C., and A. Samwick (1998): "How Important Is Precautionary Saving?," Review of Economics and Statistics, 80, 410-419.

Chan, S., And H. Stevens (2004): "Do Changes in Pension Incentives Affect Retirement? A Longitudinal Study of Subjective Retirement Expectations," Journal of Public Economics, 88, 1307-1333.

de Grip, A., M. Lindeboom, and R. Montizana (2009): "Shattered Dreams: The Effects of Changing the Pension System Late in the Game," Discussion Paper 4034, Institut zur Zukunft der Arbeit (IZA).

Deaton, A., and C. Paxson (1994): "Intertemporal Choice and Inequality," Journal of Political Economy, 102, 437-467.

Diamond, P., and J. Hausman (1984): "Individual retirement and savings behavior," Journal of Public Economics, 23, 81-114.

Disney, R., and S. Tanner (2003): "What Can We Learn from Retirement Expectations Data?," Finance and Economics Discussion Series 2003-20, Institute for Fiscal Studies.

Dwyer, D. S., And O. Mitchell (1999): "Health Problems as Determinants of Retirement: Are Self-Rated Measures Endogenous?," Journal of Health Economics, 18, 173-193.

Euwals, R., D. van Vuuren, and R. Wolthoff (2010): "Early Retirement Behaviour in the Netherlands: Evidence From a Policy Reform," De Economist, 158, 209-236.

Frederick, S., G. Loewenstein, and T. O'donoghue (2002): "Time Discounting and Time Preference: A Critical Review," Journal of Economic Literature, 40, 351-401.

Guiso, L., T. Jappelli, and D. Terlizzese (1992): "Earnings uncertainty and precautionary saving," Journal of Monetary Economics, 30, 307-337. 
HALl, R. (1978): "Stochastic Implications of the Life Cycle-Permanent Income Hypothesis: Theory and Evidence," Journal of Political Economy, 86, 971-987.

Heckman, J. (1974): "Life Cycle Consumption and labor Supply: An Explanation of the Relationship between Income and Consumption over the Life Cycle," American Economic Review, 86, 188-194.

Holtz-Eakin, D., D. Joulfaian, and H. Rosen (1993): "The Carnegie Conjecture: Some Empirical Evidence," Quarterly Journal of Economics, 108, 413-435.

Hurd, M. (2009a): Developments in the Economics of Agingchap. The Effect of Large Capital Gains or Losses on Retirement, pp. 127-171. University of Chicago Press.

Hurd, M. (2009b): "Subjective probabilities in Household Surveys," Annual Review of Economics, 1, 543-562.

Imbens, G., D. Rubin, and B. Sacerdote (2001): "Estimating the Effect of Unearned Income on Labor Earnings, Savings, and Consumption: Evidence from a Survey of Lottery Players," American Economic Review, 91, 778-794.

Kapteyn, A., R. Alessie, and A. Lusardi (2005): "Explaining the Wealth Holdings of Different Cohorts: Productivity Growth and Social Security," European Economic Review, 49, 1361-1391.

Kapteyn, A., And K. De Vos (1984): Social Security Programs and Retirement around the Worldchap. Social Security and Retirement in the Netherlands, pp. 269-303. University Of Chicago Press.

MeYer, B. (1995): "Natural and Quasi-Experiments in Economics," Journal of business Es economic statistics, 13, 151-161.

Mitchell, O., J. Poterba, and M. Warshawsky (1999): "New Evidence on the Money's Worth of Individual Annuities," American Economic Review, 89, 1299-1318.

Mundlak, Y. (1978): "On the Pooling of Time Series and Cross Section Data," Econometrica, 46, 69-85.

Poterba, J. (2000): "Stock Market Wealth and Consumption," Journal of Economic Perspectives, 14, 99-118.

Samwick, A. (1998): "Evidence on Pensions, Social Security, and the Timing of Retirement," Journal of Public Economics, 70, 207-236. 
Skinner, J. (1996): Is Housing Wealth a Sideshow? chap. Advances in the Economics of Aging, pp. 241-268. University of Chicago Press.

van der Schors, A., R. Alessie, and M. Mastrogiacomo (2007): "Home and mortgage ownership of the Dutch elderly; explaining cohort, time and age effects," Discussion Paper 77, CPB Netherlands Bureau for Economic Policy Analysis.

van Duijn, M., M. Lindeboom, P. Lundborg, and M. Mastrogiacomo (2008): "Pension Plans and the Retirement Replacement Rates in the Netherlands," Discussion Paper 118, CPB Netherlands Bureau for Economic Policy Analysis. 


\section{Appendix}

We show the theoretical underpinning of the statement that the planned retirement age depends on wealth rates. The second part of the appendix exploits a quasi natural experiment on Dutch institutions to show the effect of exogenous changes in pension wealth on retirement age.

\section{A.1 Relation between retirement age and wealth}

Hereby we prove our statement in section 3.1, page 6 . Typically one wants to maximize the utility function:

$$
U_{i}=\int_{0}^{R_{i}} e^{-\delta t}\left(u\left(c_{i t}\right)-a_{i}\right) d t+\int_{R_{i}}^{T} e^{-\delta t} u\left(c_{i t}\right) d t
$$

subject to

$$
\int_{0}^{R_{i}} e^{-r t} w_{i} d t+e^{-r t} A_{0}=\int_{0}^{T} e^{-r t} c_{i t} d t
$$

The Lagrangian for the problem is:

$$
\begin{array}{r}
\phi=\int_{0}^{R_{i}} e^{-\delta t}\left(u\left(c_{i t}\right)-a_{i}\right) d t+\int_{R_{i}}^{T} e^{-\delta t} u\left(c_{i t}\right) d t+ \\
\lambda\left(e^{-r t} A_{0}-\int_{0}^{R_{i}} e^{-r t}\left(c_{i t}-w_{i}\right) d t-\int_{R_{i}}^{T} e^{-r t} c_{i t}\right) d t
\end{array}
$$

Let us drop the household $i$ and time $t$ subscripts for simplicity. This has the first order conditions:

$$
\begin{gathered}
\frac{\partial \phi}{\partial c}=0 \Leftrightarrow \lambda=U^{\prime}(c) \frac{\delta\left(1-e^{-r T}\right)}{r\left(1-e^{-\delta T}\right)} \\
\frac{\partial \phi}{\partial R}=0 \Leftrightarrow \lambda=\frac{a}{w} e^{-(r-\delta)} \\
\frac{\partial \phi}{\partial \lambda}=0 \Leftrightarrow c\left(1-e^{-r T}\right)=A e^{-r z} r+w\left(1-e^{-r R}\right)
\end{gathered}
$$

To investigate the households optimal retirement age we could specify the household utility function. For instance a simple $\log$ utility $U_{t}\left(c_{t}\right)=\log \left(c_{t}\right)$. 
In order to keep the problem simple we solve for $\mathrm{R}$, under the assumption that the discount factor and the individual discount rate are equal, or that they drop out. This results into the following first order conditions:

$$
\begin{gathered}
\frac{\partial \phi}{\partial c}=0 \Leftrightarrow \lambda=U^{\prime}(c) \\
\frac{\partial \phi}{\partial R}=0 \Leftrightarrow \lambda=\frac{a}{w} \\
\frac{\partial \phi}{\partial \lambda}=0 \Leftrightarrow A=c T-R w
\end{gathered}
$$

Their solution is:

$$
R=\frac{T}{a}-\frac{A}{w}
$$

which implies a negative relation between retirement age and the wealth rate.

\section{A.2 Difference-in-difference analysis of the reform of the early re- tirement schemes}

We find that private wealth has a small effect on the retirement decision, both when we take the stock and the unexpected flow. A reform of the early retirement schemes in 2006 allows us to compare the effect of private wealth on the planned retirement age (as found above) with the effect of pension wealth. The reform reduced the early retirement rights of individuals born after 1949 with approximately 25 percent $^{12}$ and implied a reduction in the level of pension wealth of approximately 8 percent (de Grip, Lindeboom, and Montizaan 2009).

To quantitatively assess the effect of the reduction in early retirement wealth on the planned retirement age we take three steps. First, we estimate the average treatment effect of the reform on the planned retirement age. This effect includes both a wealth effect and a price effect due to change in the relative price of leisure. Second, we compute the magnitude of the reduction in pension wealth using details about individuals earnings histories in the DHS. Third, we relate the reduction in pension wealth to the change in the planned retirement age. Given that we estimate the average impact of the reform we have to differentiate between the pension wealth effect and price effect. To estimate the effect of (early) retirement wealth on the planned retirement age we use a difference-in-difference strategy.

${ }^{12}$ See CPB memorandum 76, CPB, The Hague, page 3 for calculations. 
Figure 3 shows the planned retirement age for employees born in 1950 or later who are affected by the 2006 reform and for employees born before 1950 who are not affected by the reform. It seems that the announcement of the reform in 2005 initially leads to a decrease in the expected retirement age for workers who are not affected by the reform and an increase in the expected retirement age for treated workers. This does not provide any direct evidence whether individuals postpone retirement because of the reduction in early retirement wealth, the actuarially adjustment of the retirement schemes or because of other effects, like macro-economic effects, changes in preferences or more awareness due to intense discussions in the media.

Figure 3: Treatment effect of the 2006 VPL reform $^{a}$

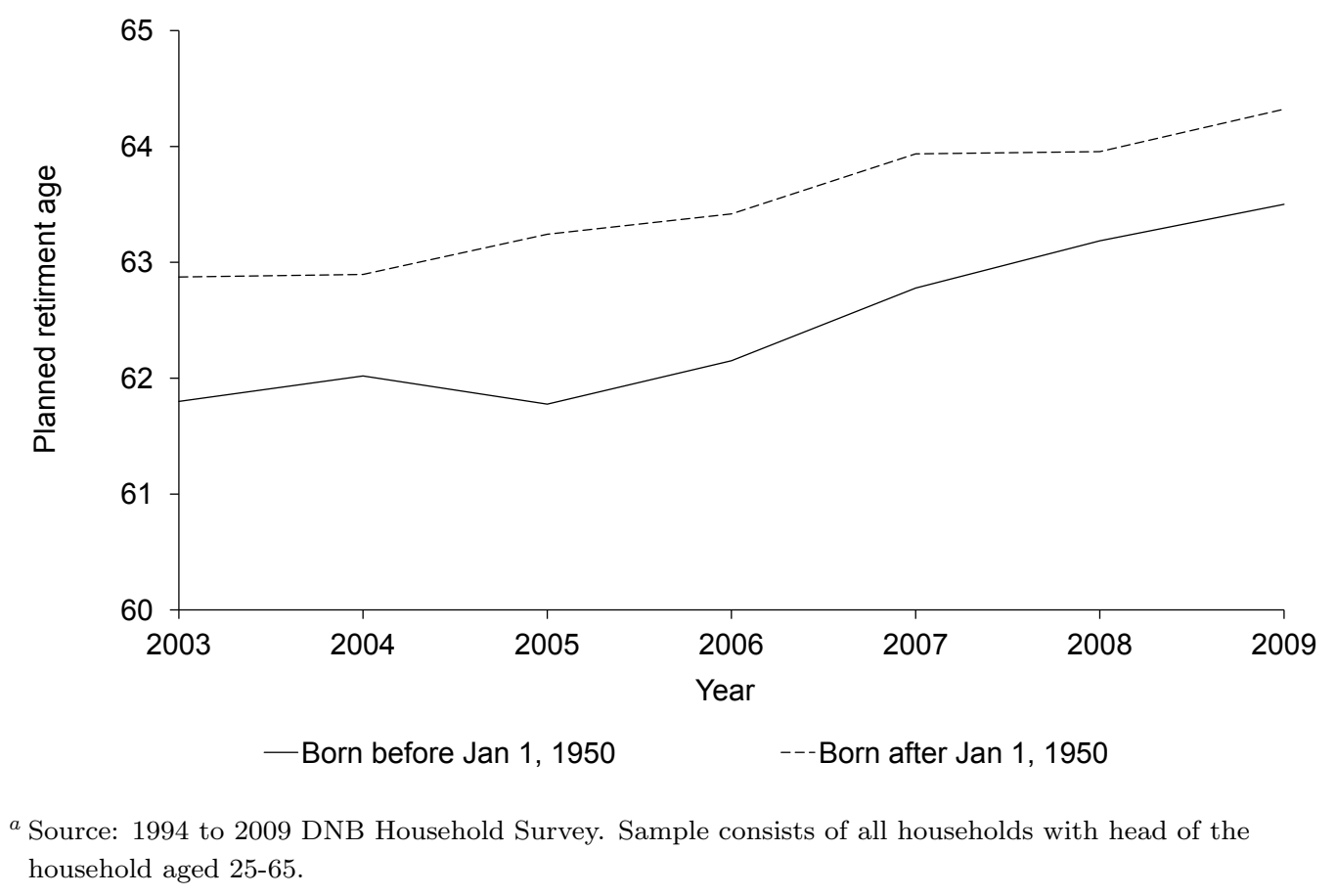

A difference-in-difference strategy allows us to isolate the causal impact of the reform on retirement plans. ${ }^{13}$ A difference-in-difference estimator compares the difference in the planned retirement before and after the reform for households that are affected by the reform (treatment group) and households that are not affected by the reform (control group). Since we subtract the difference in the planned retirement age of the control group, that is not affected, from the difference in the planned retirement age of the treatment group, that is affected, we account for these common effects. We restrict our period of analysis from 2003

${ }^{13}$ See Meyer (1995) for an extensive discussion of this empirical method. 
to 2009 in order to avoid our results to be affected by earlier reforms of the early retirement schemes, which took place from the second half of the 1990's. Further no individuals in the treatment group after 2005 are observed before 2003 because the question about the planned retirement age is not asked to those in that cohort before 2003.

The identification of the impact of the reform relies on some important assumptions (Meyer 1995). First, the assignment to the control or treatment group should be independent from the planned retirement age. People are randomly assigned to both groups on the basis of their year of birth (e.g. born before or after 1949) which is clearly exogenous with respect to the planned retirement age.

Second, the control and treatment group should be comparable over time in absence of the reform. Table 6 shows summary statistics of the control and treatment group in the period before the reform (2003 to 2004). The table shows that the workers in the treatment group expect to retire one year later compared to the control group. This might be related to earlier reforms of the early retirement schemes. The treatment group is younger compared to the control group since they are separated by year of birth. The other characteristics are quite comparable, apart from the years of pension contributions and financial wealth, which are both related to age.

Third, the reform should be clearly exogenous with respect to the planned retirement age. This implies that the reform should not be implemented to offset differences in the planned retirement age between the treatment and control group. As we mentioned, the reason for the reform was the very low labor participation and productivity of the elderly workers, which is clearly exogenous with respect to the planned retirement age.

To further control for the possibility that differences in the planned retirement age are due to different characteristics in the treatment and control group, we estimate a standard regression model for the planned retirement age controlling for these factors. Including these control variables also increases the efficiency of the difference-in-difference estimator (Meyer 1995). We estimate the following equation using standard regression (OLS):

$$
y_{i t}=\beta_{0} \alpha_{i t}+X_{i t}^{\prime} \beta_{1}+M_{i t} \delta_{1}+\text { Post }_{i t} \delta_{1}+M_{i t} \text { Post }_{i t} \delta_{2}+\epsilon_{i t}
$$

where $y_{i t}=$ Planned retirement age, $\alpha_{i t}=$ constant, $X_{i t}^{\prime}=$ Vector of socio-economic characters of household $i$ in year $t$, such as age, gender, marital status, number of children, education, health, employment status (private or public) and the number of contributing years to the pension fund; $M_{i t}=$ Treatment group: equals 1 for the individuals born after 1949 and 0 otherwise; Post ${ }_{i t}=$ Indicator of the reform: equals 1 for the period after the reform and 0 for the period before $2005 ; M_{i t} P_{o s t}{ }_{i t}=$ Interaction term: captures the change 
Table 6: Summary Statistics (control and treatment group) ${ }^{a}$

\begin{tabular}{|c|c|c|c|c|}
\hline \multirow[b]{2}{*}{ Planned retirement age } & \multicolumn{2}{|c|}{ Control group } & \multicolumn{2}{|c|}{ Treatment group } \\
\hline & 61.8 & 1.6 & 63.0 & 2.6 \\
\hline Total wealth ${ }^{b}$ & 10.2 & 9.9 & 8.2 & 11.1 \\
\hline Net financial wealth ${ }^{b}$ & 2.6 & 4.7 & 1.9 & 4.0 \\
\hline Net housing wealth ${ }^{b}$ & 6.7 & 7.6 & 5.6 & 7.5 \\
\hline Years of contribution to the pension fund & 30.5 & 7.5 & 26.3 & 10.0 \\
\hline Net income $(€ 1,000)$ & 35.1 & 16.6 & 33.9 & 46.0 \\
\hline Permanent income $^{c}(€ 1,000)$ & 26.8 & 11.2 & 25.0 & 11.5 \\
\hline Age & 56.7 & 1.6 & 52.1 & 2.1 \\
\hline Gender (male) & 0.76 & 0.41 & 0.88 & 0.32 \\
\hline Education (high) & 0.34 & 0.49 & 0.40 & 0.50 \\
\hline Education (intermediate) & 0.33 & 0.47 & 0.32 & 0.46 \\
\hline Education (low) & 0.34 & 0.47 & 0.28 & 0.45 \\
\hline Health (good) & 0.81 & 0.41 & 0.81 & 0.38 \\
\hline Health (poor) & 0.19 & 0.41 & 0.19 & 0.38 \\
\hline Family size & 2.08 & 0.79 & 2.59 & 1.36 \\
\hline Partner (yes) & 0.76 & 0.41 & 0.69 & 0.45 \\
\hline Civil Servant & 0.34 & 0.49 & 0.24 & 0.44 \\
\hline Number of observations & 67 & & 146 & \\
\hline
\end{tabular}

\footnotetext{
${ }^{a}$ Source: authors tabulations of 2003 to 2009 DNB Household Survey. Sample consists of all

households with head of the household aged 25-65. All euro amounts are in 2009 euros. The statistics use sample weights.

${ }^{b}$ Divided by permanent income.
}

in the planned retirement age for the group affected by the reform relative to the group that is not affected by the reform; $\epsilon_{i t}=$ Error term that is independently and identically distributed, with zero mean and variance $\sigma_{\epsilon}^{2}$.

Table 7 reports the estimated coefficients and the standard errors. After controlling for the different characteristics of the treatment and control group, we estimate a differencein-difference effect of the reform of 0.485 , although the effect is significant only at the 10 $\%$ level. This may be due to the low numer of observations in our sample. The other coefficients of the included explanatory variables have a similar sign and coefficient as in the regression analysis but are, except for the level of education, not statistically significant. The reduction of pension wealth with approximately 8 percent induces households to increase the planned retirement age on average with six months. We have calculated on the basis of the DHS that the mean pension wealth of Dutch households is $€ 680,000$ (van Duijn, Lindeboom, Lundborg, and Mastrogiacomo 2008). This implies that a reduction in the level of pension wealth with one yearly salary results in a reduction of the planned retirement age with approximately 3.5 months. We thus find an income effect of -28.5 percent. 
In order to interpret this result we have to differentiate between the pension wealth effect and the price effect. For the Netherlands, Euwals, van Vuuren, and Wolthoff (2010) find that the price effect is about three times as large as the wealth effect. ${ }^{14}$ This implies a pension wealth effect of about -9.5 percent, which falls in the range of the estimated effect of private wealth on the planned retirement age (e.g. between - 7.5 percent and -18 percent) and is similar to earlier estimates of the effect of pension wealth on the retirement decision. The literature finds a income effect of approximately -11 percent for pension wealth (see Euwals, van Vuuren, and Wolthoff (2010)).

Table 7: Diff-in-diff of VPL on the planned retirement age ${ }^{a}$

$\begin{array}{ll}\text { Treatment effect } & 0.485^{*} \\ \text { Born after 1949 } & 0.413 \\ \text { Post reform } & -0.324 \\ \text { Regressors } & \\ \text { Net financial wealth } & \\ \text { Net housing wealth }^{b} & -0.031 \\ \text { Contributing years to the pension fund } & -0.006 \\ \text { Higher education } & 0.002 \\ \text { Intermediate education } & 0.995^{* *} \\ \text { Poor health status } & 0.619 \\ \text { Male } & -0.044 \\ \text { Partner } & 0.363 \\ \text { Family size } & 2.171^{* * *} \\ \text { Civil servant } & -0.082 \\ \text { Permanent income }(€ 1,000) & 0.492 \\ \text { Constant } & -0.036 \\ \text { Observations } & 59.473^{* * *} \\ \end{array}$

\footnotetext{
${ }^{a}$ Source: authors tabulations of 2003 to 2009 DNB Household Survey. Sample consists of all households with head of the household aged 25-65 and working. All euro amounts are in 2009 euros. The statistics use sample weights.

$* * *$ is significant at $1 \%$ level; $* *$ is significant at $5 \%$ level; $*$ is significant at $10 \%$ level.We use heteroskedasticity- robust standard errors and cluster on the household as suggested by Bertrand, Duflo, and Mullainathan (2004)

${ }^{b}$ Divided by permanent income.
}

\footnotetext{
${ }^{14}$ Euwals, van Vuuren, and Wolthoff (2010) evaluate the reforms of the early retirement systems in the late 1990's towards a more actuarially fair scheme. Using data from the Dutch Income Panel Study (IPO) between 1989 and 2000, they estimate a small but significant pension wealth effect. They find that a decrease of the level of pension wealth by one yearly salary induces workers to postpone retirement by two months.
} 